\title{
JOMSTI
}

JDURNAL DF MUSIL

\section{MERLOT: Belajar Musik di Era Digital}

\author{
Riyan Hidayatullah \\ Program Studi Pendidikan Seni Musik, Fakultas Keguruan dan Ilmu Pendidikan, \\ Universitas Negeri Lampung \\ email: riyanhidayatullah@gmail.com
}

\begin{abstract}
This article is a literature review on MERLOT (Multimedia Education Resources for Online Learning and Teaching), an open-source multimedia-based learning resource for asynchronous music learning needs. Conventional music learning methods that deal with practical activities and theory classes. This activity is usually done in a classical or private class. In addition to general problems in music pedagogy and psychology, access to music materials in the form of music theory, music forms, and music literature is a problem that is specifically for music teachers in Indonesia. Access and publishing of music books are still minimal. These kinds of stuff carry out music teachers with non-music educational backgrounds to arrange music materials systematically, find out credible music learning resources, the latest issues about music learning and digital tools that can be used for online music courses. Various pieces of literature show that MERLOT is contributing to information literacy, digital, and supporting the learning of music nowadays.
\end{abstract}

Keywords: MERLOT, asynchronous, information literacy, music learning.

\begin{abstract}
ABSTRAK
Artikel ini merupakan kajian literatur tentang MERLOT (Multimedia Educational Resource for Learning and Online Teaching), sebuah sumber pembelajaran terbuka berbasis multimedia untuk kebutuhan pembelajaran musik asinkronus. Metode pembelajaran musik konvensional umumnya berhubungan dengan kegiatan praktik dan kelas teori. Kegiatan ini biasa dilakukan di dalam kelas secara klasikal atau privat. Selain masalah-masalah umum dalam pedagogi dan psikologi musik, akses terhadap materi-materi musik berupa teori musik, bentuk musik, dan literatur musik menjadi masalah tersendiri bagi para guru musik di Indonesia. Akses dan ketersediaan buku-buku musik masih sangat terbatas. Ini menjadi guru-guru musik yang berlatar belakang pendidikan non-musik untuk menyusun materi-materi musik secara sistematis, mencari sumber-sumber pembelajaran musik yang kredibel, mengetahui isu-isu terbaru tentang pembelajaran musik dan perangkat digital yang dapat digunakan untuk pembelajaran musik. Berbagai literatur menunjukan MERLOT memberikan kontribusi dalam literasi informasi, digital, dan metodologi dalam pembelajaran musik saat ini.
\end{abstract}

Kata kunci: MERLOT, asinkronus, literasi informasi, pembelajaran musik. 


\section{PENDAHULUAN}

Di beberapa negara, pendidikan musik menghadapi persoalan dan perhatian khusus. Di Singapura, pendidikan musik digunakan untuk fokus mengejar tujuan holistik pendidikan sekolah dasar di dalam sistem pendidikannya (Lum \& Dairianathan, 2014). Di Australia, lima dari enam negara bagian memiliki pengawas musik yang melekat pada Departemen Pendidikan mereka (Bartle, 1968). Di Jerman, pendidikan musik yang diajarkan selalu bertolak dari pengalaman (Sukmayadi, 2014). Sementara di Indonesia, pendidkan musik masih menghadapi persoalan metodologi dalam mengajar dan miskonsepsi terhadap istilah-istilah musik (Mack, 2007). Di samping hal ini tentu masih banyak persoalan-persoalan yang melatarbelakangi masalah musik di Indonesia.

Para praktisi pendidikan sepakat bahwa mengajar merupakan sebuah aktivitas kompleks (Ball, 2000; Clark \& Lampert, 1986; Dewey, 1964; P. Grossman, 1990; Pam Grossman, Hammerness, \& McDonald, 2009; Shulman, 1986). Guru merupakan fasilitator yang harus memiliki kualitas, pemahaman, kompetensi, kemampuan, dan keterampilan untuk menerjemahkan materi yang akan diajarkan (Ball, 2000; P. Grossman, 1990; Pam Grossman et al., 2009; Shulman, 1986). Pengetahuan konten saja tidak cukup untuk mengajar musik, tetapi memerlukan kemampuan pedagogi yang cukup untuk untuk memenuhi kemampuan praktik yang kompleks (Ball, 2000; Ballantyne, 2006; Millican, 2016). Latar belakang guru musik yang beragam di Indonesia menuntut mereka untuk menguasai kemampuan lain, di luar kemampuan musik, misalnya penguasaan teknologi.

Di era teknologi yang semakin maju saat ini, pendidikan konvensional semakin tidak populer karena perubahan internal yang sangat dinamis (Yates \& Tilson, 2002). Kemampuan teknologi dalam pendidikan musik berguna untuk memperluas tujuan kurikulum dan memungkinkan untuk praktik lintas disiplin (Coutinho \& Mota, 2011; Savage, 2005). Tetapi, perlu diingat, bahwa perubahan konten kurikulum perlu diimbangi dengan perubahan pedagogi (Green, 2001).

Tren pembelajaran saat ini mulai berubah mengikuti perkembangan sosialbudaya di masing-masing daerah. Kondisi perubahan tersebut diperngaruhi cara berinteraksi masyarakat yang semakin mengarah ke dunia virtual (deNoyelles \& Seo, 2011). Masyarakat, khususnya peserta didik lebih dekat dengan dunia digital. Kedekatan siswa dan media sosial ini dimanfaatkan oleh para guru untuk 
membawanya ke dalam kurikulum (Dreon, Kerper, \& Landis, 2011). Binkley (2018) membuat sebuah konten video yang diunggah ke youtube. Seluruh siswa yang mengakses video tersebut memberikan komentar di kolom yang disediakan. Ini merupakan cara Binkley untuk menilai pastisipasi murid-muridnya.

Tercatat sekitar 73,1\% dari laporan yang diterbitkan tentang OER (Open Educational Resources) terkonsentrasi di antara tahun 2010 dan 2013 (Zancanaro, Todesco, \& Ramos, 2015). OER adalah sebuah sumber pembelajaran berlisensi terbuka yang dapat diakses dengan tujuan riset dan pengembangan pembelajaran tertentu (Butcher, 2015; Ebner et al., 2017; Hidayatullah, 2018; Hylén, Damme, Mulder, \& D’Antoni, 2012; Pryde, 2009; Rolfe, 2012; Sclater, 2011; Yuan, MacNeill, \& Kraan, 2008). Saat ini OER banyak digunakan dalam pembelajaran kelas terbuka (open learning) diberbagai institusi atau konsorsium (Pryde, 2009).

Penggunaan OER pada awalnya diluncurkan tahun 2008 oleh Open.Michigan (https://open.umich.edu/) untuk menyediakan akses publik terhadap produk akademik (Cohen, Omollo, \& Malicke, 2014). OER berkembang dalam berbagai format dan platform, seperti PDF, PPT, slideshare.net, youtube.com, dan amara.org.

Istilah OES (open educational services) dan OER (open educational resources) memiliki makna sebagai sebuah sumber pembelajaran terbuka. Istilah 'terbuka' (open) memiliki makna nyaman, efektif, terjangkau, berkelanjutan, dan tersedia bagi pelajar dalam skala besar (Downes, 2007; Walker, 2005). Dengan demikian, sebagai media pembelajaran OER dan OES merupakan sebuah sumber pembelajaran yang dapat diakses dengan lisensi terbuka atau gratis.

Banyak kesalahan persepsi mengenai OER, OES dengan pembelajaran elektronik (e-learning). Pembelajaran elektronik dapat memanfaatkan OER atau OES, tetapi tidak berarti OER dan OES harus digunakan dalam pembelajaran elektronik (Butcher, 2015: 6).

Hylén (2005) mendefinisikan OER sebagai berikut:

1) konten dan courseware

2) aplikasi pembelajaran terbuka (seperti: Leraning Management System)

3) materi terbuka untuk mengembangkan kapastitas e-learning bagi staf pengajar

4) repositori objek pembelajaran

5) kursus gratis. 
OER memiliki konten-konten jaringan pendidikan profesional terbuka (Open Professionals Education Network) terbuka yang dapat diakses secara gratis (“Openmichigan," 2016), seperti mesin pencari umum (google, CC search, flicker, yahoo), video (youtube, vimeo, TED), musik/audio (jomendo, soundcloud, free music archive), pendidikan (OER commons, open yale courses), kelas (virtual) (open learning initiative, open course library, Open University Learning Space, saylor.org) dan komponen kelas modular (connexions, curriki, MERLOT) ("Find OER | Open Professionals Education Network," 2019). OER semakin berkembang dan bertransformasi menjadi MOOCs (Massive Open Online Courses). MOOCs merupakan cabang berikutnya dalam proses berkelanjutan evolusi OER (Hanley, 2015: 33).

MOOCs adalah salah satu contoh OES (layanan pendidikan terbuka) Sederhananya, OES adalah alat online yang gratis untuk digunakan siapa pun untuk merancang program mereka sendiri belajar menggunakan OER atau konten yang eksklusif. Berbagai macam materi gratis dan materi pengajaran tersedia secara terbuka di web yang dapat ditinjau di MERLOT (Multimedia Education Resources for Online Learning and Teaching) atau sumber daya multimedia multimedia untuk pembelajaran dan pengajaran online, bersama dengan seperangkat alat gratis untuk memungkinkan pembelajaran bagi semua orang (Hanley, 2015:35).

MERLOT adalah proyek internasional yang berupaya memfasilitasi evaluasi dan penggunaan bahan ajar dan pembelajaran online (Shea, McCall, \& Ozdogru, 2006). Perpustakaan digital terbuka tidak lagi mampu mengakomodir kebutuhan konten pembelajaran. Layanan ini terus berkembang untuk memenuhi kebutuhan orang untuk berkomunikasi dan berkolaborasi. MERLOT merupakan jawaban atas kebutuhan sosial yang begitu tinggi di internet. Sama seperti media sosial, MERLOT menyediakan layanan berbasis keomunitas yang dapat berkomunikasi secara sinkron dan asinkron, mengunggah informasi, blog, dan layanan suara ("MERLOT," 2019). Walaupun belum banyak yang mengetahui tentang MERLOT dan penggunaannya masih sangat terbatas (Shea et al., 2006), layanan ini dapat menjadi alternatif pembelajaran (khususnya di perguruan tinggi) dalam menerapkan kelas terbuka.

Dalam layanan pencarian (musik khususnya), MERLOT menyediakan berbagai tipe, seperti kelas daring (online course), materi terbuka (open access material), simulasi, koleksi, kuis dan tes, presentasi, bahan ajar, dan referensi lain 
(“MERLOT Collection," 2019). Layanan lainnya adalah perpustakaan daring yang disediakan dari berbagai pengajar terkemuka seperti "Berklee College of Music" dan MIT.

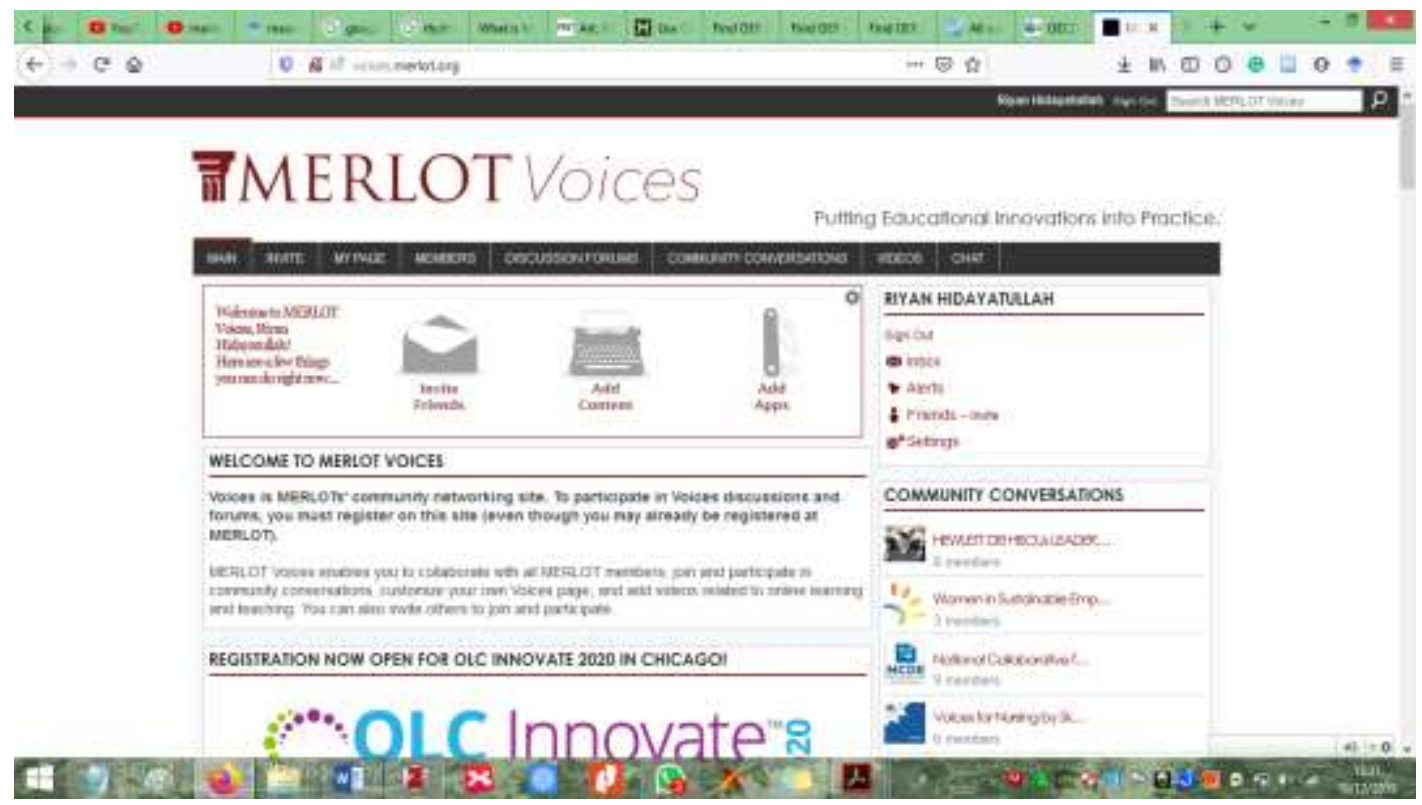

Gambar 1.

Salah satu fitur "MERLOT Voices" memungkinkan pengguna membangun kedekatan seperti media sosial pada umumnya

(“MERLOT Voices," 2019)

\section{METODE PENELITIAN}

Penulisan artikel ini menggunakan reviu literatur dengan cara analisis tema (Onwuegbuzie, Leech, \& Collins, 2012), meringkas dan mensintesis penelitian sebelumnya (Denney \& Tewksbury, 2013) yang berkaitan dengan pendidikan musik menggunakan MERLOT.

\section{PEMBAHASAN}

Moodle music merupakan salah satu layanan yang terhubung dengan MERLOT berbentuk CMS (Course Management System). CMS adalah aplikasi web yang berjalan menggunakan server dan diakses dengan menggunakan browser web (Cole \& Foster, 2008: 4). CMS merupakan alat kontruktivisme sosial dan komunitas dalam jumlah besar. Dikatakan konstruktivisme karena berangkat dari gagasan bahwa belajar adalah keterlibatan dalam proses sosial dalam membangun 
pengetahuan, singkatnya dilakukan melalui kelompok-kelompok (Cole \& Foster, 2008:5).

Materi dalam moodle music dibagi berdasarkan level dasar-dasar teori musik, seperti berikut.

1) ritmik: beat, tempo dan durasi

2) kunci dan tangga nada

3) melodi

4) interval

5) chord

6) progresi chord.

Level pada setiap materi dibagi berdasarkan tingkat kesulitan dan sesi. Setiap materi dan sub bahasannya disesuaikan dengan kompetensi apa yang ingin dicapai. Dalam materi beat dan pulsa, misalnya, definisi di awal materi menjelaskan tentang esensi pemahaman dasar seperti berikut

\section{Materi I}

In music the beat is the basic unit of time, the pulse. The beat is often defined as the rhythm listeners would tap their toes to when listening to a piece of music. In different music styles it appears in different ways. In dancing music, the beat is usually clear, often more subtle in art music. Not all music has a clear beat or pulse. We've all been listening to the pulse (heart rate) before we were born. Listen to the example below. The beat of our own heart can be calm or more intense. Measure your own heart rate as described below ("Course: Rhythm 1A: Beat, tempo and measure," 2019).

Contoh diberikan berupa video yang terhubung dengan youtube, dan latihan sebagai berikut.

Measure your own pulse

How many times per minute do your heart beats right now? Look for a point in your body where you feel your heart rate, such as your wrist, neck or throat. Measure for an entire minute or 15 seconds, whereby the result should be multiplied by four ( $4 \times 15=60$ seconds, or one minute). So if your heart beats 20 times in 15 seconds, your heart rate is 80 times per minute.

The human heart rate can vary from about 40 to 200.

("Course: Rhythm 1A: Beat, tempo and measure," 2019). 


\section{Materi II}

\section{Tabel 1.}

Kategori dalam penjabaran materi musik per sesi

Deskripsi

Materi

Definisi

pemahaman dan Tempo is a musical term that determines how rare or dense the pulse is in a song. We also talk about the speed of the piece.

Contoh

The tempo can be expressed as a number. For example, tempo 120 means 120 pulses / beats per minute. This can be marked as 120 BPM (beats per minute).

Pengembangan informasi
The pulse of the human heart is about 60-80 BPM. In music we experience such a tempo quite calm. In the music and especially in the musical notes, the metronome mark $M M=60$ is also used. This means the same as BPM, or beats per minute.

Dalam sesi ini, materi "tempo" dilatih menggunakan aplikasi sederhana, sebagai berikut.

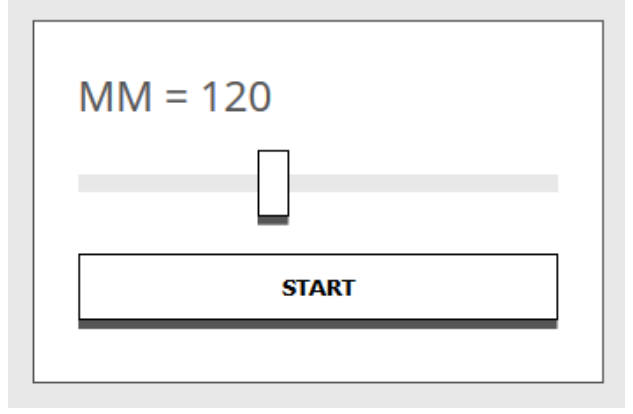

Gambar 2.

Aplikasi multimedia dalam sesi latihan "tempo". 
Dalam materi sesi ke-2 ini tersedia layanan untuk latihan: (1) mencoba memasukkan tempo mulai dari 60, 80, dan 120 BPM; (2) melakukan "tap" tempo secara beraturan untuk memunculkan jumlah tempo BPM.

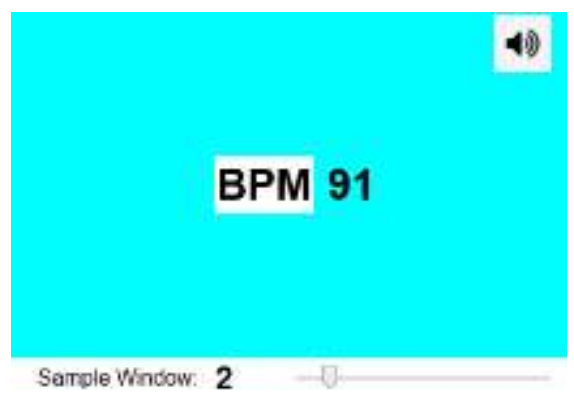

Gambar 3.

Aplikasi multimedia dalam sesi latihan "tempo".

Dalam proses selanjutnya melibatkan kemampuan metakognisi (Dunlosky \& Metcalfe, 2009; Leon-Guerrero, 2008; Nielsen, 2001; Power \& Powell, 2018; Roberts, 2011), yakni mengevaluasi tempo melalui video yang tersedia.
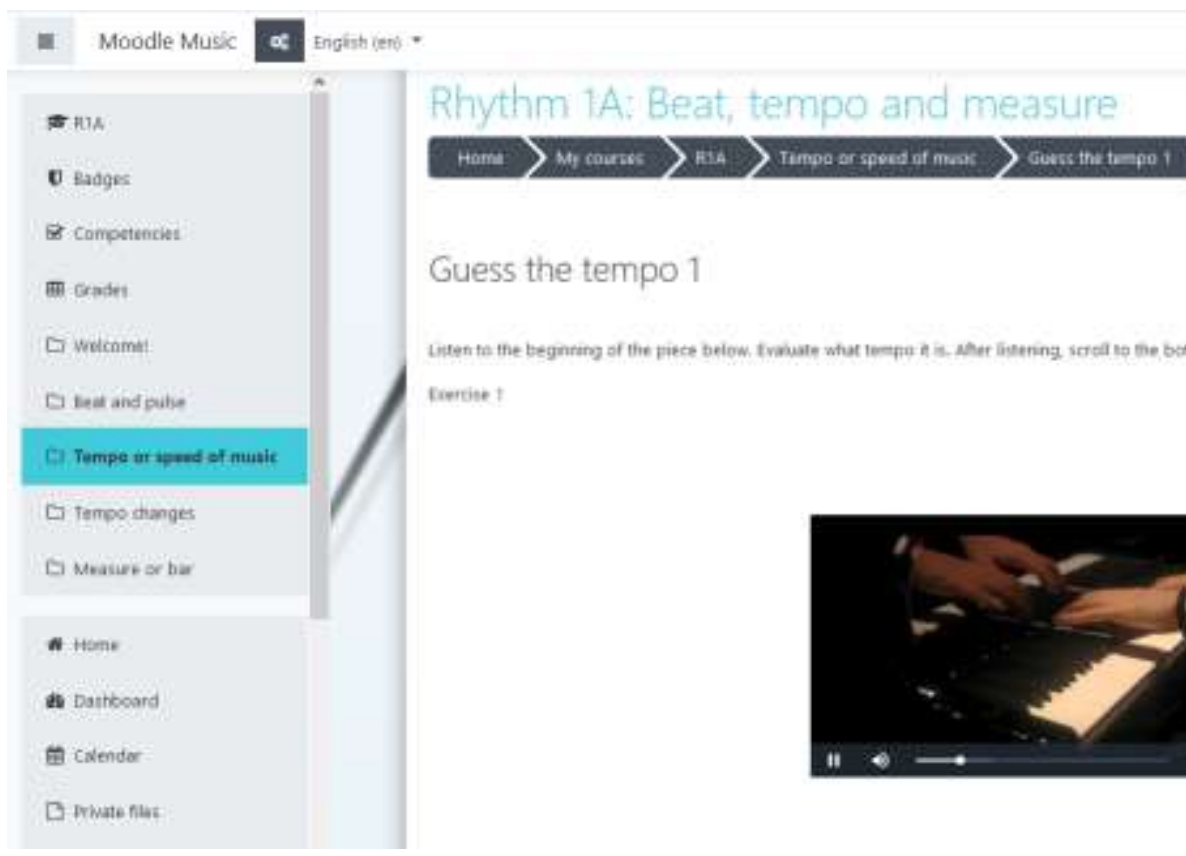

\section{Guess the tempo 1}

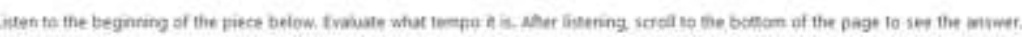

tuerise :

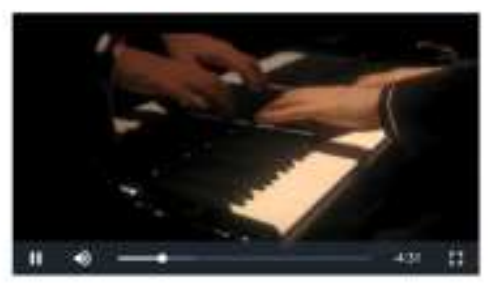

Gambar 4.

Mengevaluasi tempo dalam video 


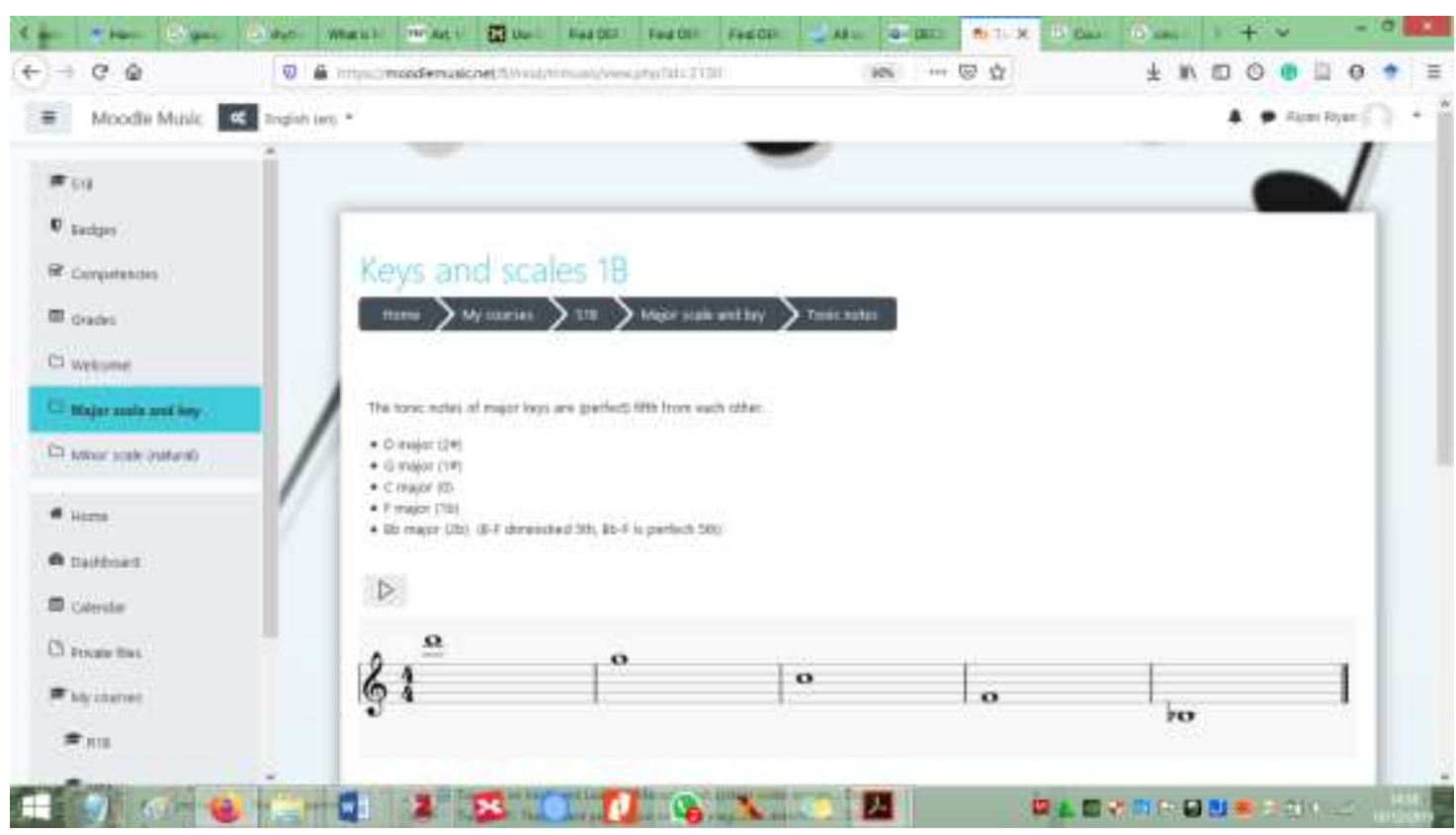

Gambar 4.

Sub materi pada pembelajaran kelas daring "moodle music"

(“Tonic notes," 2019)

Penyedia layanan atau guru menyediakan materi dalam bentuk multimedia yang dapat diputar melalui "klik" tombol "play". Materi berupa nada-tonik dalam interval perfect-fifth dengan nilai empat ketuk per nada. Materi ini memberikan gambaran visual dan auditif tentang sebuah nada di dalam garis paranada (staff). Materi di atas adalah aplikasi yang memberikan alternatif belajar musik melalui internet. Modalnya adalah koneksi internet. Seluruh materi yang disajikan sistematis seperti yang terdapat dalam buku-buku teori musik. Kelebihannya adalah materi disajikan dalam multimedia, ini adalah salah satu kata kunci dari MERLOT. Para pembelajar dapat merasakan pengalaman visual dan auditif. Selain itu, MERLOT juga memberikan fasilitas bagi pada pengajar di sekolah dan perguruan tinggi dalam mengembangkan teknologi akademik yang terukur, pendidikan yang berkelanjutan dan berkualitas tinggi (Hanley, 2001; Hanley, Schneebeck, \& Zweier, 1998; Schneebeck \& Hanley, 2001).

Aplikasi ini (moodle music) memfasilitasi para peserta didik untuk menerapkan konsep learning community (Baker, Terry, Bridger, \& Winsor, 1997), artinya berkomunikasi dan membangun makna (belajar) bersama-sama (Calderwood, 2000), tetapi tetap memiliki kontrol (Bartlett \& Turkanis, 2001). Belajar menjadi 
sebuah kegiatan kolaborasi, saling mendorong dan mendukung, mengajukan pertanyaan, memberikan bantuan, dan menanggapi (Brophy, Alleman, \& Knighton, 2010). Kegiatan ini dilakukan melalui forum diskusi yang memungkinkan peserta dan pengguna untuk saling berinteraksi dalam sistem moodle. Pengguna (moodle music) dan pengembang dapat bekerja sama untuk memastikan kualitas, tambahan modul, fitur-fitur terbaru, dan ide-ide lain (Cole \& Foster, 2008:5). Pada akhirnya, komunikasi online melalui teknologi merupakan berkah sekaligus beban. Di satu sisi membatu aspek-aspek teknik yang tertera dalam materi-materi musik yang ada dalam buku, di sisi lain dapat menggantikan pengalaman belajar secara tatap muka (Caine \& Caine, 2010:26).

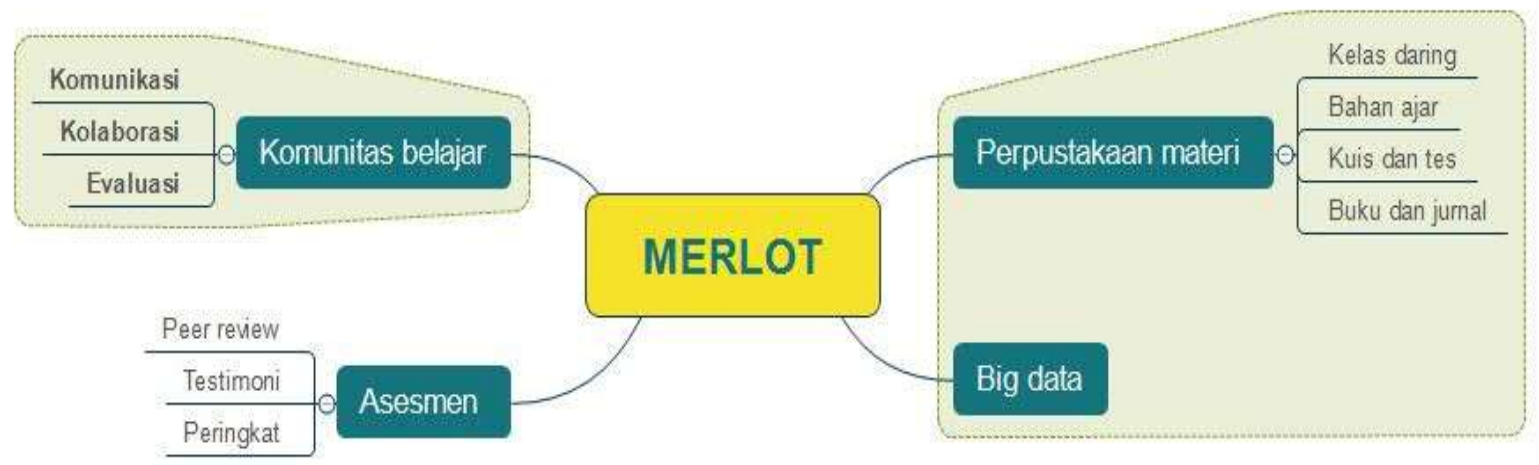

Diagram 1. Konfigurasi MERLOT sebagai sebuah media pembelajaran

MERLOT secara simultan menyediakan lebih dari 80.000 materi-materi yang ada (termasuk musik) dan perputakan OER (OER libraries). Informasi secara detail dapat dilihat melalui keterangan, temasuk asesmen terkait kualitas seperti peer review ("MERLOTPlace," 2019). MERLOT adalah sebuah "komunitas", memasuki berbagai portal komunitas dari berbagai disiplin ilmu. Ini adalah sebuah konsep pembelajaran berbasis komunitas di era digital.

Pengguna dapat membuat konten melalui content builder dengan MERLOT sebagai web-hostingnya. Kolaborasi dapat dilakukan antar sesama pengguna MERLOT dengan lisensi umum (common license). Dengan seluruh ketersediaan data yang sangat besar, MERLOT merupakan sebuah manifestasi kecil dari big data (Dumbill, 2012; Hurwitz, Nugent, Helper, \& Kaufman, 2013). Seperti facebook atau media sosial lainnya, MERLOT bisa berfungsi sebagai alat untuk mencapai tujuan 
belajar yang sangat efektif karena dilengkapi dengan fitur dan server yang kuat. Platform ini dapat digunakan sebagaimana penggunaan media sosial lainnya. Kunci keberhasilan pembelajaran berbasis media sosial adalah kenyamanan, koneksi sosial, suasana informal, insidental, dan pembelajaran berbasis sosial (Mao, 2014:221). Prinsip ini bisa diterapkan dalam pembelajaran menggunakan MERLOT agar aplikasi ini dikenal secara luas.

\section{SIMPULAN}

Dalam pembelajaran musik, MERLOT tidak hanya mengakomodir kebutuhan teori tetapi juga pada tataran praktis. Fungsi yang sangat besar ini perlu disebarluaskan melalui berbagai kebijakan institusional dan fitur-fitur yang mudah digunakan (user friendly). Suasana berlajar yang informal menjadi salah satu kunci untuk membuat para siswa nyaman menggunakan platform ini. Secara ontologis dan epistemologis, media sosial merupakan tantangan bagi dunia akademisi (Hemmi, Bayne, \& Land, 2009). Ada makna yang hilang dari interaksi belajar dengan teman sejawat (Ashraf, 2009). Perlu dipahami bahwa siswa tidak hidup di dalam ruang hampa, tetapi proses interaksi dalam belajar dipengaruhi oleh masyarakat dan budya melalui teknologi (Gredler, 2009). Kurikulum harus berangkat dari gagasan liberalisme dan progresif, tetapi harus mengedepankan konservativisme berupa nilai-nilai dalam belajar.

\section{REFERENSI}

Ashraf, B. 2009. Teaching the Google-eyed YouTube generation. Education + Training, 51(5/6), 343-352. https://doi.org/10.1108/00400910910987165

Baker, J. A., Terry, T., Bridger, R., \& Winsor, A. 1997. Schools as caring communities: A relational approach to school reform. School Psychology Review, 26(4), 586-602.

Ball, D. L. 2000. Bridging practices: Intertwining content and pedagogy in teaching and learning to teach. Journal of Teacher Education, 51(3), 241-247. https://doi.org/10.1177/0022487100051003013

Ballantyne, J. 2006. What Music Teachers Want: The Emergence of a Unified Understanding of an Ideal Teacher Education Course. Australian Journal of Teacher Education, 31(1). https://doi.org/10.14221/ajte.2006v31n1.1

Bartle, G. 1968. Music in Australian schools. Victoria: ACER. 
Bartlett, L., \& Turkanis, C. G. 2001. The Classroom Community "in Control." In B. Rogoff, C. G. Turkanis, \& L. Bartlett (Eds.), Learning together: Children and adults in a school community (pp. 86-90). New York: Oxford University Press.

Binkley, T. 2018. Circle graph/ pie chart data table tutorial [Online]. Retrieved November 9, 2019, from Youtube website: https://www.youtube.com/user/MrBinkley6\#p/a

Brophy, J. E., Alleman, J., \& Knighton, B. 2010. A learning community in the primary classroom. New York: Routledge.

Butcher, N. 2015. A basic guide to open educational resources (OER) (A. Kanwar \& S. Uvalic'-Trumbic', Eds.). Commonwealth of Learning and UNESCO.

Caine, G., \& Caine, R. N. 2010. Strengthening and enriching your professional learning community: The art of learning together. Alexandria, Va: ASCD.

Calderwood, P. E. 2000. Learning community: Finding common ground in difference. New York: Teachers College Press.

Clark, C., \& Lampert, M. 1986. The study of teacher thinking: Implications for teacher education. Journal of Teacher Education, 37(5), 27-31. https://doi.org/10.1177/002248718603700506

Cohen, J. Z., Omollo, K. L., \& Malicke, D. 2014. A Framework to Integrate Public, Dynamic Metrics Into an OER Platform. Open Praxis, 6(2). https://doi.org/10.5944/openpraxis.6.2.118

Cole, J., \& Foster, H. 2008. Using moodle: Teaching with the popular open source course management system (2nd ed.). United States of America: O'Reilly Media.

Course: Rhythm 1A: Beat, tempo and measure [CMS]. 2019. Retrieved December 10, 2019, from Moodle Music website: https://moodlemusic.net/fi/course/view.php?id=62\#section-0

Coutinho, C., \& Mota, P. 2011. Web 2.0 technologies in music education in Portugal: Using podcasts for learning. Computers in the Schools, 28(1), 56-74. https://doi.org/10.1080/07380569.2011.552043

Denney, A. S., \& Tewksbury, R. 2013. How to Write a Literature Review. Journal of Criminal Justice Education, 24(2), 218-234. https://doi.org/10.1080/10511253.2012.730617

deNoyelles, A., \& Seo, K. K. 2011. Understanding communication processes in a 3d online social virtual world. In Teaching arts and science with the new social media. Retrieved from http://www.myilibrary.com?id=305529

Dewey, J. 1964. John Dewey on education (A. R, Ed.). Chicago, IL: University of Chicago Press. (Original work published 1904).

Downes, S. 2007. Models for sustainable open educational resources. Interdisciplinary Journal of E-Skills and Lifelong Learning, 3(1), 29-44. https://doi.org/10.28945/384 
Dreon, O., Kerper, R. M., \& Landis, J. 2011. Digital storytelling: A tool for teaching and learning in the youtube generation. Middle School Journal, 42(5), 4-10. https://doi.org/10.1080/00940771.2011.11461777

Dumbill, E. 2012. What is big data? In Big data now: Current perspectives from O'Reilly Media. (pp. 3-9). United States of America: O'Reilly Media, Inc.

Dunlosky, J., \& Metcalfe, J. 2009. Metacognition. Thousand Oaks, CA: Sage.

Ebner, M., Lorenz, A., Lackner, E., Kopp, M., Kumar, S., Schön, S., \& Wittke, A. 2017. How OER enhance MOOCs-A Perspective from German-Speaking Europe. In Open Education: From OERs to MOOCs (pp. 205-220). Retrieved from https://link.springer.com/chapter/10.1007/978-3-662-52925-6_11

Find OER | Open Professionals Education Network [Webpage]. 2019. Retrieved December 10, 2019, from Open Professionals Education Network website: http://open4us.org/find-oer/

Gredler, M. E. 2009. Learning and instruction: Theory into practice. New Jersey: Upper Saddle River.

Green, L. 2001. How popular musicians learn: $A$ way ahead for music education. Aldershot: Ashgate.

Grossman, P. 1990. The making of a teacher: Teacher knowledge and teacher education. New York: Teachers College Press.

Grossman, Pam, Hammerness, K., \& McDonald, M. 2009. Redefining teaching, reimagining teacher education. Teachers and Teaching, 15(2), 273-289. https://doi.org/10.1080/13540600902875340

Hanley, G. L. 2001. Designing and delivery of instructional technology. A teambased approach. In B. C. \& H. P. (Eds.), Technology-enhanced learning: $A$ guide to engaging and supporting faculty (pp. 57-64). San Francisco: JosseyBass.

Hanley, G. L. 2015. MOOCs, MERLOT, and open educational services. In C. J. Bonk, M. M. Lee, T. C. Reeves, \& T. H. Reynolds (Eds.), MOOCs and open education around the world (pp. 33-40). New York: Routledge.

Hanley, G. L., Schneebeck, C., \& Zweier, L. 1998. Implementing a scalable and sustainable model for instructional software development. , 11(9), 30-4. Syllabus, 11(9), 30-34.

Hemmi, A., Bayne, S., \& Land, R. 2009. The appropriation and repurposing of social technologies in higher education: Social technologies in higher education. Journal of Computer Assisted Learning, 25(1), 19-30. https://doi.org/10.1111/j.1365-2729.2008.00306.x

Hidayatullah, R. 2018, September. Oer, open access-digital literacy in art education technology based. Proceeding presented at the Proceeding of International Indonesia Conference on Interdisciplinary Studies: State and Digital Society, Lampung University, Indonesia. Retrieved from http://iicis.fisip.unila.ac.id/

Hurwitz, J., Nugent, A., Helper, F., \& Kaufman, M. 2013. Big data for dummies. Retrieved from www.wiley.com 
Hylén, J. 2005. Open educational resources: Opportunities and challenges. OECDCERI. Retrieved from http://www.oecd.org/dataoecd/1/49/35733548.doc

Hylén, J., Damme, D. V., Mulder, F., \& D’Antoni, S. 2012. Open educational resources: Analysis of responses to the OECD country questionnaire. OECD Education Working Papers, (76), 1-33. http://dx.doi.org/10.1787/5k990rjhvtlven

Leon-Guerrero, A. 2008. Self-regulation strategies used by student musicians during music practice. Music Education Research, 10(1), 91-106. https://doi.org/10.1080/14613800701871439

Lum, C.-H., \& Dairianathan, E. 2014. Mapping musical learning: An evaluation of research in music education in Singapore. International Journal of Music Education, 32(3), 278-295. https://doi.org/10.1177/0255761413491206

Mack, D. 2007. Art (music) education in Indonesia: A great potential but a dilemmatic situation. Educationist, 1(2), 62-74.

Mao, J. 2014. Social media for learning: A mixed methods study on high school students' technology affordances and perspectives. Computers in Human Behavior, 33, 213-223. https://doi.org/10.1016/j.chb.2014.01.002

MERLOT Collection [Webpage]. 2019. Retrieved December 10, 2019, from MERLOT

website: https://www.merlot.org/merlot/materials.htm?keywords=music+online+course \&sort.property=relevance

MERLOT [Education]. 2019, December 9. Retrieved December 9, 2019, from MERLOT website: https://www.merlot.org/merlot/materials.htm?keywords=music\&sort.property=r elevance

MERLOT Voices [Webpage]. 2019. Retrieved December 10, 2019, from MERLOT Voices website: http://voices.merlot.org/

MERLOTPlace [Video Sharing]. 2019. Retrieved December 11, 2019, from YouTube website: https://www.youtube.com/channel/UCBsTK-e_dli-F0rrjDx50w

Millican, J. S. 2016. Describing preservice instrumental music educators' pedagogical content knowledge. Update: Applications of Research in Music Education, 34(2), 61-68. https://doi.org/10.1177/8755123314552664

Nielsen, S. 2001. Self-regulating Learning Strategies in Instrumental Music Practice. Music Education Research, 3(2), 155-167. https://doi.org/10.1080/14613800120089223

Onwuegbuzie, A. J., Leech, N. L., \& Collins, K. M. T. 2012. Qualitative Analysis Techniques for the Review of the Literature. The Qualitative Reports, 17(56), $1-28$.

Openmichigan [Website]. 2016, October 18. Retrieved December 10, 2019, from Open Educational Resourses website: https://open.umich.edu/share/openeducational-resources/use-open-content 
Power, A. M., \& Powell, S. J. 2018. Engaging young string players in metacognition. International Journal of Music Education, 36(4), 659-670. https://doi.org/10.1177/0255761418771989

Pryde, J. 2009. Open educational resources and the universal library initiative. Retrieved from San Jose State University School of Library and Information Science.

Roberts, S. 2011. Metacognition in music performance: A practical approach to implementing self-assessment and evaluation learning activities into teaching practice. Making Sound Waves: Diversity, Unity, Equity: Proceedings of the XVIII National Conference, 170-177.

Rolfe, V. 2012. Open educational resources: Staff attitudes and awareness. Research in Learning Technology, 20, 1-13. https://doi.org/10.3402/rlt.v20i0/14395

Savage, J. 2005. Information communication technologies as a tool for re-imagining music education in the 21st century. International Journal of Education \& the Arts, 6(2). Retrieved from http://www.ijea.org/v6n2/.

Schneebeck, C., \& Hanley, G. L. 2001. The California State University Center for distributed learning. In E. R.M. \& B. A.W. (Eds.), Teaching faculty how to use technology: Best practices from leading institutions. Westport, CT: Greenwood/Oryx Press.

Sclater, N. 2011. Open educational resources: Motivations, logistics and sustainability. In N. Ferrer \& J. M. Alonso (Eds.), Content management for $e-$ learning (pp. 179-193). New York: Springer.

Shea, P., McCall, S., \& Ozdogru, A. 2006. Adoption of the multimedia educational resource for learning and online teaching (MERLOT) among higher education faculty: Evidence from the State University of New York learning network. MERLOT Journal of Online Learning and Teaching, 2(3), 12.

Shulman, L. S. 1986. Those who understand: Knowledge growth in teaching. Educational Researcher, 15(2), 4-31. https://doi.org/doi:10.3102/0013189x015002004

Sukmayadi, Y. 2014. Musik Kontemporer dalam Kurikulum dan Buku Sekolah di Jerman. Resital: Jurnal Seni Pertunjukan, 15(2), 169-178. https://doi.org/10.24821/resital.v15i2.851

Tonic notes [CMS]. 2019. Retrieved December 10, 2019, from Moodle Music website: https://moodlemusic.net/fi/mod/mmusic/view.php?id=2130

Walker, E. 2005. A reality check for open education. Utah. Presented at the Open Education Conference. Retrieved from http://cosl.usu.edu/media/presentations/opened2005/OpenEd2005-

WalkerEd.ppt [slides] and http://www.archive.org/audio/audio-detailsdb. php?collection=opensource_audio\&collectionid=OpenEd2005ARealityCheckf orOpenEducation [audio]

Yates, C., \& Tilson, T. 2002. Basic education at a distance: An introduction. In C. Yates \& J. Bradley (Eds.), Basic education at a distance: World review of 
distance education and open learning (1st ed., Vol. 2, pp. 3-26). Retrieved from https://www.taylorfrancis.com/books/9780203187623

Yuan, L., MacNeill, S., \& Kraan, W. 2008. Open educational resources-opportunities and challenges for higher education. Educational Cybernetics: Reports. Paper 1, 1-34.

Zancanaro, A., Todesco, J. L., \& Ramos, F. 2015. A bibliometric mapping of open educational resources. International Review of Research in Open and Distributed Learning, 16(1), 1-23. 